\title{
垂直下降流における沸騰開始点の特性
}

\author{
亀田 貴俊*1, 網 健行*2, 梅川 尚嗣 ${ }^{* 3}$
}

\section{Characteristics of onset of boiling under downward flow condition}

\author{
Takatoshi KAMEDA*1 ${ }^{*}$, Takeyuki AMI ${ }^{* 2}$ and Hisashi UMEKAWA*3 \\ ${ }^{{ }^{1} 1,{ }^{*},{ }^{*} 3}$ Department of Mechanical Engineering, Kansai University \\ 3-3-35 Yamate-cho, Suita-shi, Osaka 564-8680, Japan
}

Received: 30 September 2019; Revised: 17 December 2019; Accepted: 20 February 2020

\begin{abstract}
Understanding of the onset of boiling plays an important role in the design of boiling equipment. Therefore, many studies have been reported so far, but most of these concerned with the upward flow condition. Moreover, the onset of boiling condition in downward flow is complex due to stagnant and/or reverse bubble caused by buoyancy force on thermal-nonequilibrium flow field, thus the correlation for upward flow cannot be applied directly to downward flow. The purpose of this study is to clarify the characteristics of onset of boiling under downward flow. In the experiment, the onset of boiling condition was measured by using several size of test sections under upward and downward flow conditions. Experimental results expressed the typical two kinds of tendencies, i.e. thermal dominant and the thermal-fluid dominant conditions, with the difference of heating length of test section. In the case of thermal-fluid dominant condition, the difference between upward and downward flows was also clearly observed. On the basis of experimental results, the modified Bowring's and modified Levy's correlations are proposed for each region, and these modified correlations show good agreements with the experimental results in each condition.
\end{abstract}

Keywords : Boiling two-phase flow, Downward flow, Onset of boiling, Subcooled boiling, Pressure drop

\section{1. 緒言}

サブクール水が蒸発部に流入する沸騰関連機器では，沸騰開始点を境に液単相流から気液二相流へと遷移する ため，圧力損失特性が変化し，伝熱機構が対流伝熱から沸騰伝熱へと遷移する.さらに，条件によっては沸騰開 始条件そのものが DNB 発生条件や，ドライアウト予測における二相流開始条件となる，そのため，これまでに も垂直上昇流の沸騰開始条件に関しては，様々な研究が報告されており，たとえば Lahey ら（Lahey and Moody， 1977）は，垂直上昇流のサブクール沸騰域を，2 つの領域に大別している．具体的には伝熱面表面に沸騰気泡が 付着，あるいはスリップしながら下流へ移流し，合体や凝縮を繰り返して成長する Wall voidage 領域を経て，沸 騰気泡が伝熱面から離脱し，ボイド率が急激に上昇する，Detached voidage 領域に至る．前者の領域では，伝熱面 表面で沸騰・凝縮を繰り返しているため，正味のボイド率は非常に小さく，主に後者の領域の開始条件を正味沸 騰開始点として，様々な相関式（Bowring, 1962，Levy, 1967，Saha and Zuber, 1974 などがあり，日本機械学会, 2006 に詳しい）が提案されている．古典的かつ代表的なモデルとして，Levy は，壁面に付着した気泡に作用する力の バランスと, 液単相乱流の温度分布から沸騰開始点を決定するモデルを提案したが，熱的な要因が加味されてい ないことが指摘されている。これに対し，Saha らは，気泡の蒸発率と凝縮率による熱的な要因が気泡離脱条件に 対して支配的になる低流量域と，流れが支配的となる高流量域に分けてそれぞれ相関式を提案している。これら のモデルは適用性にまだ議論はあるものの，基本的な考え方としては広く認知されている.

No.19-00359 [DOI:10.1299/transjsme.19-00359], J-STAGE Advance Publication date : 3 March, 2020

本論文は，第24回動力・エネルギー技術シンポジウム 講演論文集(2019), No.A134の掲載内容に基づいた論文である.

*1 学生員, 関西大学大学院 理工学研究科 機械工学専攻（テ564-8680 大阪府吹田市山手町 3-3-35)

*2 正員, 関西大学 システム理工学部 機械工学科

*3 正員, フェロー, 関西大学 システム理工学部 機械工学科

E-mail of corresponding author: t ami@kansai-u.ac.jp 
一方，垂直下降流の沸騰開始条件については，研究報告例が非常に少なく，知見が十分に得られていないのが 現状である. 垂直下降流では上昇流の場合とは異なり, 浮力の影響により, 初期沸騰気泡はエンタルピの低い上 流部へと逆流し, 凝縮することで発生する潜熱輸送, あるいは境界層を攪拌することで顕熱輸送を促進するなど, 複㮅な伝熱流動現象が生じているものと考えられる．Bibeau ら（Bibeau and Salcudean, 1990）は，ガンマ線を用い た沸騰下降流のボイド率計測を行い, 下降流の沸騰開始クオリティは上昇流よりも低くなることを報告しており， 従来の垂直上昇流を対象とした沸騰開始モデルをそのまま下降流に適用することができないことを示唆している. そこで本研究では, 上昇流および下降流の伝熱実験を行い, 圧力損失特性から沸騰開始点を見積もり, 垂直下降 流の沸騰開始条件に関する相関式について検討したので報告する.

\section{2. 実験装置および実験方法}

本実験で用いた実験装置（図 1（a)）は，十分に脱気したイオン交換水を作動流体とする強制流動沸騰系であ る.リザーバータンクに貯められた水をポンプにより圧送し, ローターメータで流量を調節した後に, タービン フローメータ（測定精度士 $3.86 \mathrm{~mL} / \mathrm{min}$ ）を用いて流量を計測する．また，プレヒータで所定の入口流体温度に調 節し，上昇流の場合はテストセクション下部から，下降流の場合はテストセクション上部から流入させる. テス トセクションを交流電源により直接通電加熱し, 加熱部で発生した蒸気をセパレータで汽水分離し, 液をリザー バータンクに戻す．なお，加熱部からの放熱量は投入熱量の $1 \%$ 以下であるため，本研究ではその影響は無視す る. テストセクション（図 1 (b) ) は, 管外径 $16 \mathrm{~mm}$, 管内径 $15 \mathrm{~mm}$, 加熱長さ $L=600 \mathrm{~mm}$ のステンレス製円管 であり，管外壁面には $\phi 0.1 \mathrm{~mm}$ の $\mathrm{K}$ 型素線熱電対をスポット溶接により設置した. 実験では他に長さ $800 \mathrm{~mm} の$

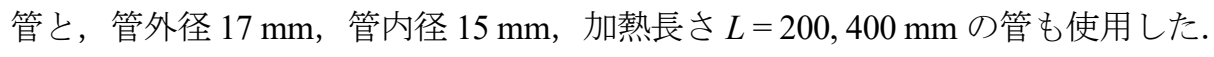

本実験では, 加熱部の熱流束を $10 \mathrm{~kW} / \mathrm{m}^{2}$ の刻みでステップ状に増加させ, テストセクション前後に設けたポー ト部を介して, テストセクション圧力損失を差圧変換器（測定精度 $\pm 0.02 \mathrm{kPa}$ ）により測定する. 入口流体温度は テストセクション上流部に設置した熱電対により測定する，なお，下降流の場合は蒸気の逆流による温度上昇が 生じるため, 逆流の影響を受けない上流域でも流体温度を測定し, その温度が一定であることをもって入口流体 温度を保証する．また，本実験ではセパレータに設置されたブルドン管での圧力を代表系圧力とする.

実験条件は系圧力 $0.3 \mathrm{MPa}$ ，入口流体温度 $60{ }^{\circ} \mathrm{C}$, 質量流束 $G=35 \sim 500 \mathrm{~kg} / \mathrm{m}^{2} \mathrm{~s}$ である.

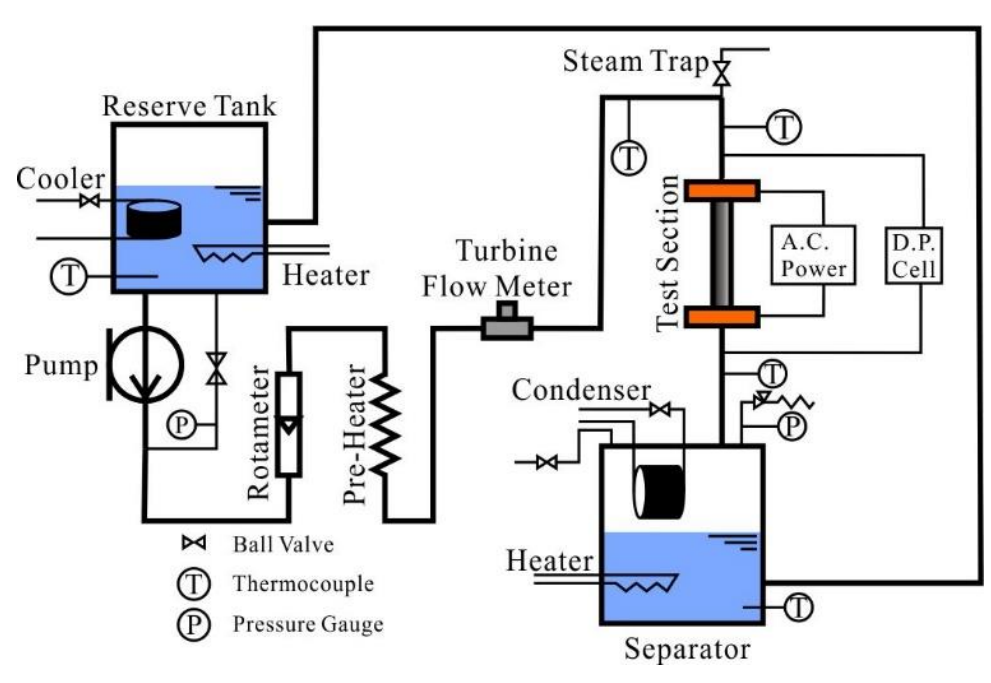

(a) Experimental loop

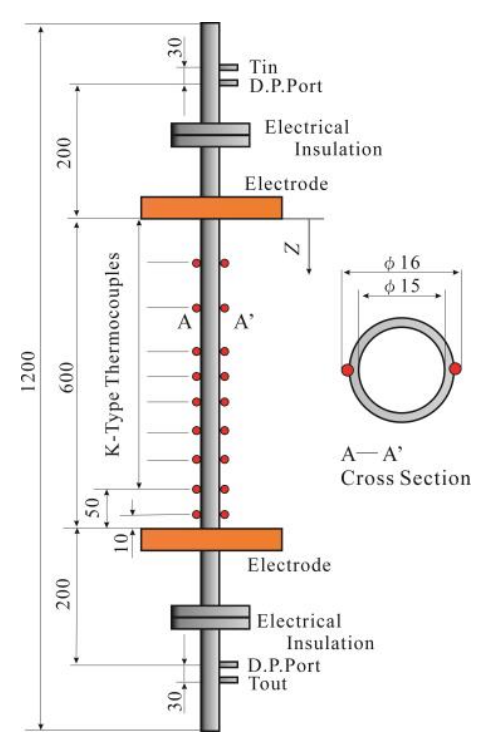

(b) Test section $(L=600 \mathrm{~mm})$

Fig. 1 Experimental apparatus for downward flow. 


\section{3. 実験結果および考察}

図 2 に実験結果の代表例として, 加熱長さ $L=600 \mathrm{~mm}$, 質量流束 $G=200 \mathrm{~kg} / \mathrm{m}^{2} \mathrm{~s}$ の上昇流（中空プロット）お よび下降流（中実プロット）におけるテストセクション圧力損失の時間平均值を, 熱流束に対してプロットした ものを示す. 図中のエラーバーはテストセクション圧力損失の変動の最大・最小值を表している. また比較対象 として,スリップ流モデルを用いて算出したテストセクション圧力損失の計算結果を成分ごとに併記する.なお, スリップ比は Wintertonの相関式を用いて見積もった. また, 上流部を基準に下流部との圧力差を測定しているた め，非加熱時には液ヘッドの位置損失により，上昇流ではプラス，下降流ではマイナスの值を取る．図より，低 熱流束（図中領域（a)）では，テストセクション圧力損失は，ほぼ一定值を示しており，エラーバーも確認でき ないことから，管内は液単相状態であると考えられる. 熱流束を増加させると（図中領域 $(b)$ ), テストセクショ ン圧力損失の時間平均值は変化しないものの, エラーバーが少し大きくなる.これは伝熱表面での沸騰・凝縮が, テストセクション圧力損失の変動として現れたものと考えられる. そのため, 本領域は前述の Wall voidage 領域 に相当すると考えられる.さらに熱流束を増加させると（図中領域 (c)), テストセクション圧力損失の時間平均 值が上昇流では低下し，下降流では上昇する．本実験系のテストセクション圧力損失は位置損失が支配的である ことから, 加熱部出口において混合平均密度の低下を引き起こす,気泡離脱によるボイド率の上昇が生じたため, このような結果が得られたものと考えられる. この領域は, 前述の Detached voidage 領域に相当するものと考え られる. 本研究では, 領域 (b) と領域 (c) の境界 (図中矢印) の条件を沸騰開始点（PNVG：Point of Net Vapor Generation）と定義する. また, 沸騰開始点条件を一律に判定するために, 本研究では, 加熱部全体が液単相状態 の場合のテストセクション圧力損失を基準として，そこから初めてある閾值以上変化した条件を沸騰開始点と判

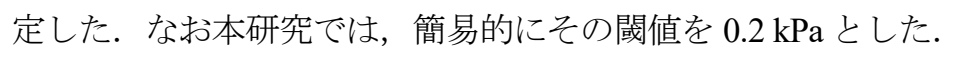

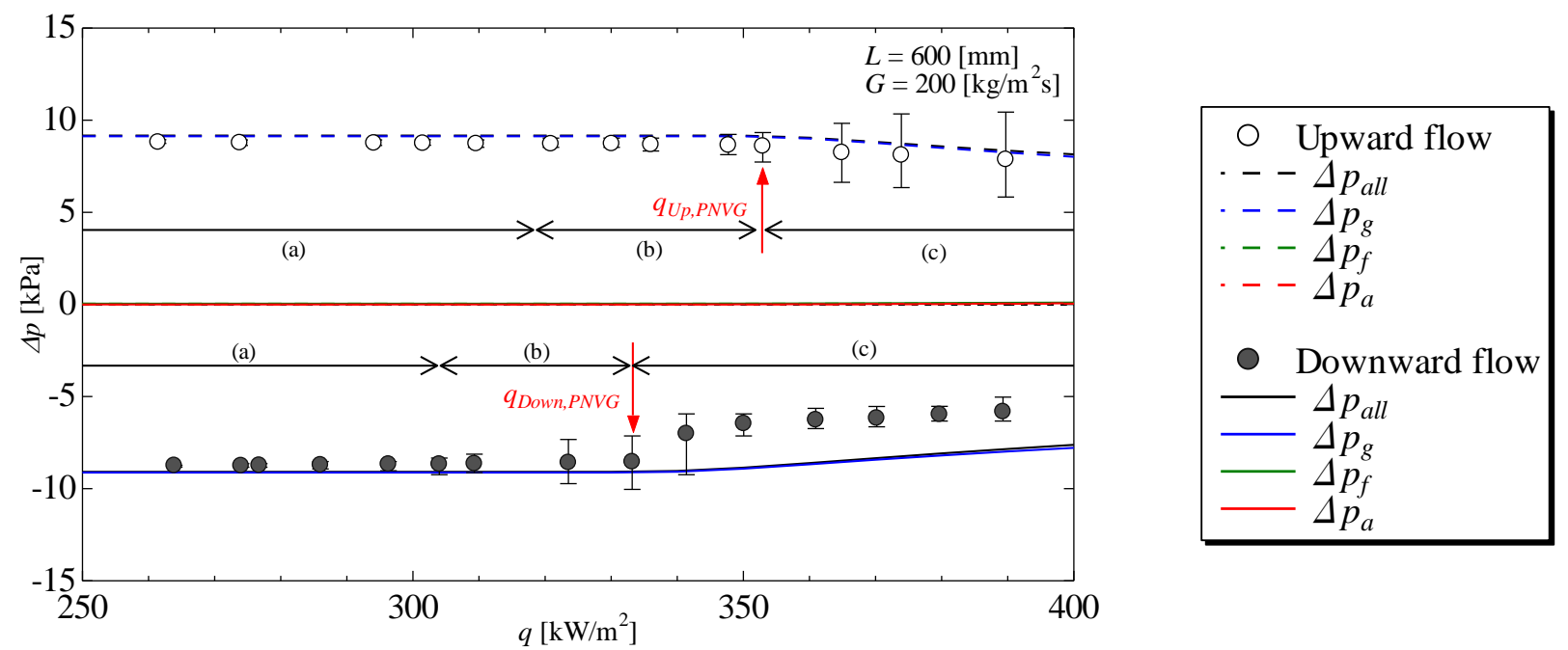

Fig. 2 Determination of point of net vapour generation (PNVG). In this investigation, PNVG condition is defined by using the characteristics of pressure drop. Time-averaged pressure drop of test section for upward and downward flows is plotted by open and solid plots, respectively, and the error bar corresponds to the pressure fluctuation. As a comparison, the calculation results by using slip flow model with each component term of pressure drop are drawn. The pressure drop characteristics are classified into 3 regions, i.e. (a) single liquid phase region, (b) wall voidage region and (c) detached voidage region. In this experiment, the data just before the region (c) (red arrow) is defined as a PNVG.

図 3 に，上昇流（中空プロット）および下降流（中実プロット）における，沸騰開始条件での加熱部出口の熱 平衡クオリティ $x_{e q, P N V G}$ を質量流束に対してプロットしたものを，加熱長さごとに示す．図中には比較対象とし て, Bowring の相関式（オレンジ破線）を用いた計算結果，Levyの相関式（緑破線）を用いた計算結果，スラグ 流のドリフト速度から求まる蒸気の逆流限界（黒破線）を併記する. 図より, 加熱長さが長い場合 $(L=600,800$ $\mathrm{mm})$, 沸騰開始クオリティは質量流束に対してほぼ一定值を示し，下降流と上昇流の沸騰開始点にあまり大きな 差が見られなかった. 沸騰開始条件を熱支配と流れ支配に分けるSaha らの整理方法に倣うと, これらの結果は質 量流束に対して感度がないことから, 沸騰開始条件は熱的要因が支配的であると考えられる.また，流量に対し 
て感度の無い Bowring の相関式が定性的に一致する傾向を示した.一方, 加熱長さが短い場合 $(L=200,400 \mathrm{~mm})$, 質量流束の増加に伴い沸騰開始点の熱平衡クオリティが大きく低下し，下降流の沸騰開始クオリティの方が上昇 流の場合よりも明らかに低くなる傾向を示した。つまりこの場合の沸騰開始条件は，熱的要因のみならず，流体 的要因も考慮する必要があると考えられる．また，現状，上昇流と下降流の沸騰開始条件の差が説明できる相関 式は存在しないものの, Levy の相関式が定性的に一致する傾向を示した，以上の結果を踏まえ，熱支配条件では Bowring の相関式，熱・流体支配条件では Levyの相関式をベースに，各パラメータをチューニングし，上昇流と 下降流における沸騰開始条件を検討する。

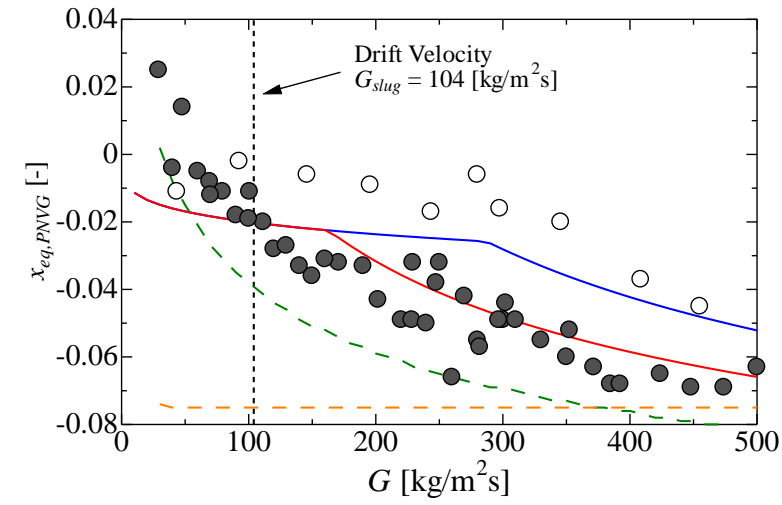

(a) $L=200 \mathrm{~mm}$

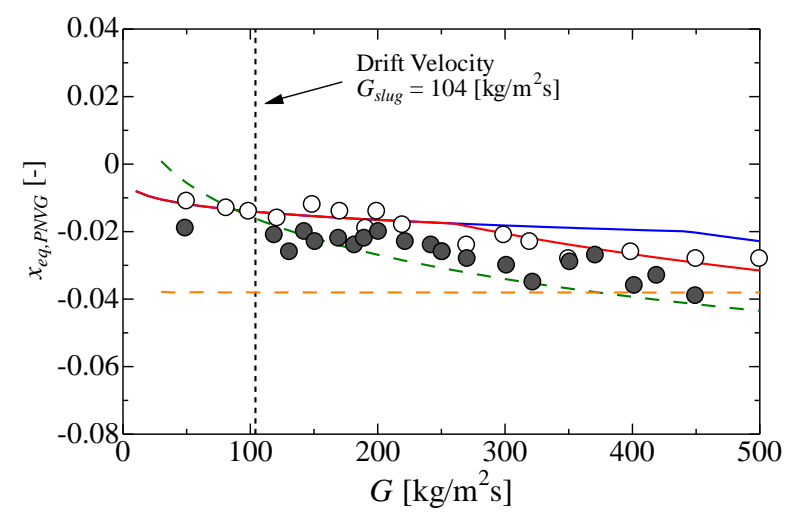

(c) $L=600 \mathrm{~mm}$

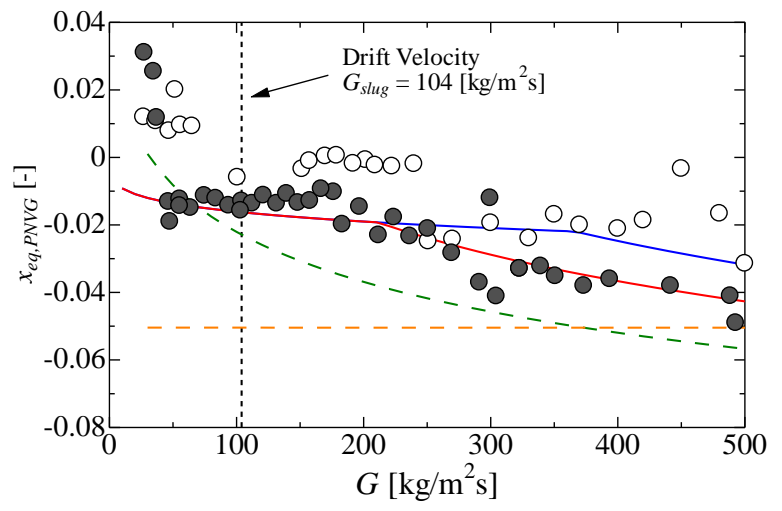

(b) $L=400 \mathrm{~mm}$

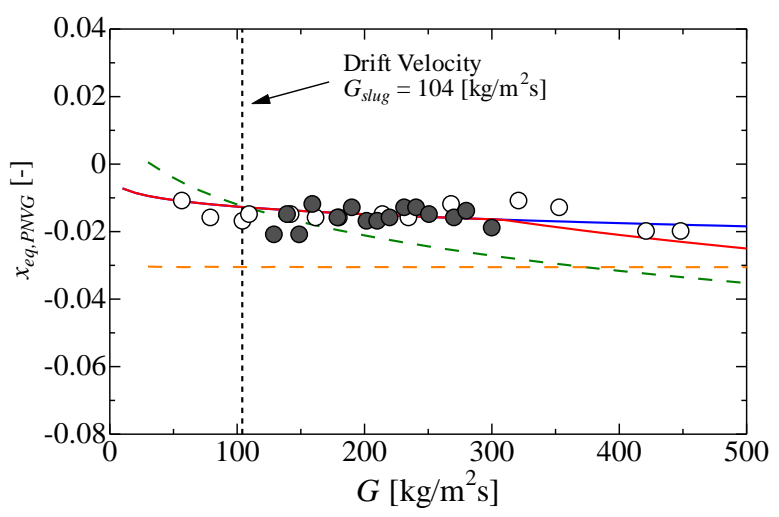

(d) $L=800 \mathrm{~mm}$

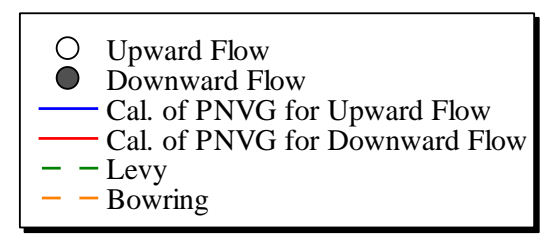

Fig. 3 Thermal equilibrium quality at PNVG. The experimental results of thermal equilibrium qualities at PNVG are plotted as a function of mass flux. The calculation results with original Levy's and Bowring's correlation are drawn by dashed lines. Proposed correlations for upward and downward flow conditions are drawn by solid lines. In the figure, stagnant mass flux condition of downward slug flow which estimated by Drift-flux model is also drawn by dashed black line. Experimental results express quite different tendencies with difference of heating length of test sections.

まず，熱支配の沸騰開始条件について検討を行う．Bowring のモデルにおいて，沸騰開始クオリティ $x_{d}$ は次式 で与えられる.

$$
x_{d}=-\frac{c_{p L}\left(T_{s a t}-T_{L}\right)}{H_{L G}}=-\frac{c_{p L}\left(T_{w}-T_{L}\right)}{H_{L G} \theta}=-\frac{c_{p L}}{H_{L G} \theta} \frac{q}{h_{\text {sub }}}
$$




$$
T_{\text {sat }}-T_{L}=\eta \frac{q \rho_{L}}{G} \quad(\eta=14+0.987 p)
$$

ここで, $c_{p L}$ は液相の定圧比熱, $H_{L G}$ は蒸発潜熱, $T_{s a}, T_{L}$,および $T_{w}$ はそれぞれ, 飽和温度, 流体の混合平均温度, 壁面温度である. 本来のモデルでは式（2）を用いて温度差を算出するのに対し，ここでは，次式の無次元温度 $\theta$ を定義することで，沸騰開始時のサブクール度を熱流束 $q$ とサブクール沸騰の熱伝達率 $h_{\text {sub }}$ で表現した.

$$
\theta=\frac{T_{w}-T_{L}}{T_{\text {sat }}-T_{L}}
$$

本研究では, サブクール沸騰は, 液単相の対流熱伝達から, 核沸騰熱伝達への遷移過程とみなし, サブクール沸 騰熱伝達率 $h_{s u b}$ を，液単相強制対流熱伝達率 $h_{L}$ と核沸騰熱伝達率 $h_{B}$ の線形補間により決定する.

$$
h_{\text {sub }}=\left(1-C_{1}\right) h_{L}+C_{1} h_{B}
$$

なお，液単相強制対流熱伝達率 $h_{L}$ と核沸騰熱伝達率 $h_{B}$ には，それぞれ Dittus-Boelter の相関式，McAdams の相関 式を用いており，以下の式で与えられる.

$$
\begin{aligned}
& h_{L}=0.023 \frac{k_{L}}{D} \operatorname{Re}^{0.8} \operatorname{Pr}^{0.4} \\
& h_{B}=1.95^{\frac{1}{3.86}} q^{\frac{1.43}{1.93}}
\end{aligned}
$$

本研究では, 無次元温度 $\theta$ およ゙係数 $C_{1}$ を，実験結果を用いてチューニングする. 図 4 に無次元温度 $\theta$ の分布を ヒストグラムで示す．なお，無次元温度は，熱支配条件に属する沸騰開始条件での壁面温度および混合平均温度 の実験結果から, 式（3）を用いて算出した。 この無次元温度は, 熱流束による沸騰開始時のサブクール度に対す る影響を簡易的に表現するものであり，沸騰開始条件が飽和温度に近づくにつれて大きな值を取る．物理的にあ る一定值を取るものではないが, 対象とする条件範囲では比較的まとまった值を取る. なお本結果では, 図より, 最頻值として $\theta=2.75$ にピークが得られたが, 最頻值を用いてサブクール沸騰熱伝達率 $h_{\text {sub }}$ 評価したところ, 核沸 騰熱伝達率よりも熱伝達率が大きくなる結果となり, 原理的に無理が生じたため, 本研究では平均值である $\theta=$ 4.96 を無次元温度の值とした.

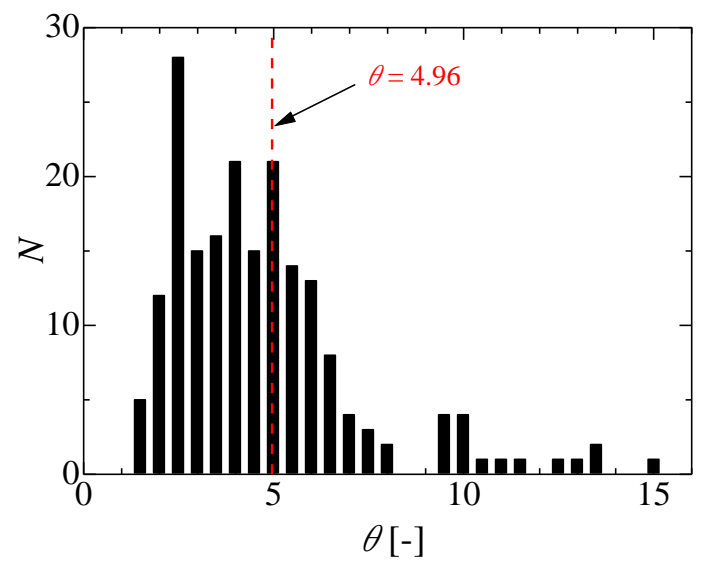

Fig. 4 Determination of dimensionless temperature. In this investigation, the non-dimensional temperature, Eq.2, is introduced, and that value is decided on the basis of experimental results. This figure expresses the number of experimental results of non-dimensional temperature. In this paper, the average value $\theta=4.96$ is used for calculation. 
また，熱支配条件の全実験結果に対し，式（4）の係数 $C_{1}$ を算出した結果を図 5 に示す．図より，係数 $C_{1}$ の值が 1 以上となる結果が多少存在するが，これらの結果は蒸気が逆流する極低流量条件，もしくは熱・流体支配条件 への遷移境界に位置する結果であることから，本条件に含めることは不適当であると考え，これらの結果を除い $\tau$, 平均値 $C_{1}=0.465$ を得た.

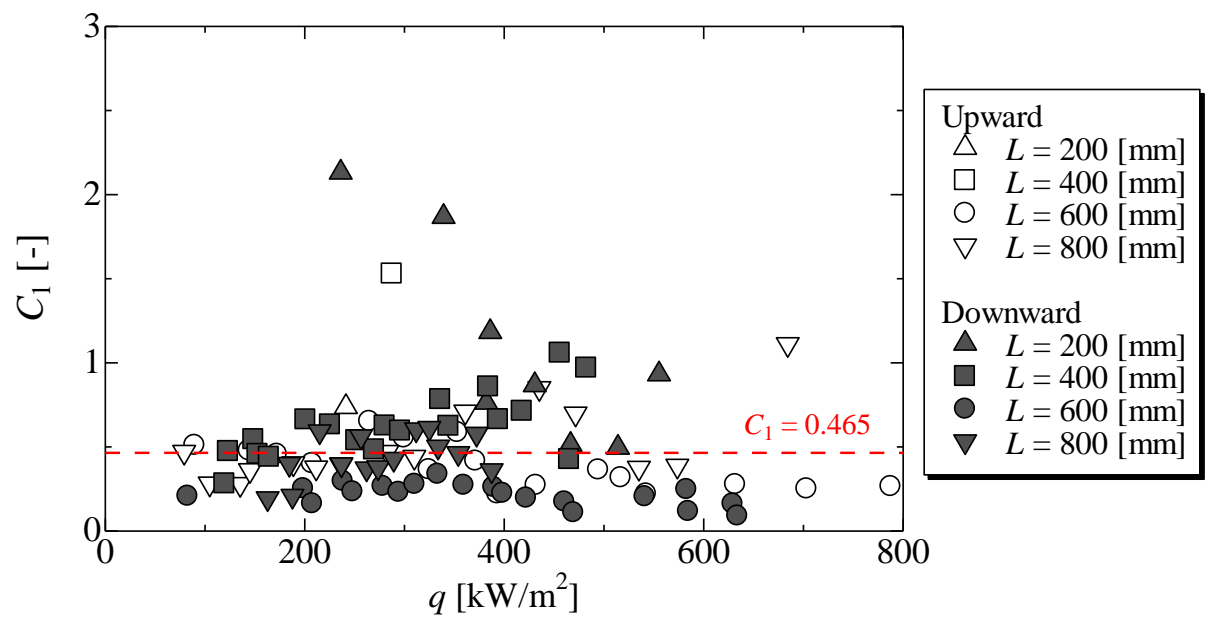

Fig. 5 Determination of $C_{1}$. The heat transfer coefficient is expressed by using $C_{1}$ in Eq.3. This figure expresses the experimental results, and the average value $C_{1}=0.465$. is used for calculation. In the estimation, the larger value than 1.0 , which may be caused by flow reversal, is ignored.

次に，熱・流体支配の沸騰開始条件を検討寸る．Levy のモデルでは，気泡に作用するカのバランスより，気泡 半径 $r_{B}$ を考え，Kárman の一般速度分布に基づき決定される温度分布において，気泡先端位置での温度が飽和温 度に等しいと考え，沸騰開始条件を与える．気泡に作用する力のバランスは，

$$
C_{B} g\left(\rho_{L}-\rho_{G}\right) r_{B}^{3}+C_{D} \frac{\tau_{w}}{D} r_{B}^{3}-C_{S} r_{B} \sigma=0
$$

ここで, $r_{B}$ は気泡半径， $g$ は重力加速度， $\tau_{w}$ は壁面せん断力， $\sigma$ は表面張力であり, 式 (7) 左辺第一項は浮力, 第二項は軸方向への推進力となる抗力, 第三項は表面張力であり, 浮力と抗力が気泡を離脱させる力として働き, 表面張力が気泡を壁面に保持する力として働く.また $C_{B}, C_{D}, C_{S}$ は離脱気泡の形状に関する係数である. 壁面か ら気泡先端までの距離を $y_{B}$ とし，式（7）を無次元化したものが次式である.

$$
Y_{B}^{+}=\frac{\rho_{L} u^{*} y_{B}}{\mu_{L}}=C_{2} \frac{\sqrt{\sigma D \rho_{L}}}{\mu_{L}}\left[1+C_{3}\left\{\frac{g\left(\rho_{L}-\rho_{G}\right) D}{\tau_{w}}\right\}\right]^{-\frac{1}{2}}
$$

ここで, $u^{*}$ は摩擦速度であり， $C_{2}$ は気泡に作用する抗力と表面張力に関する比， $C_{3}$ は気泡に作用する抗力と浮力 に関する比を表す，上昇流の実験結果に対して，Levy と同様に浮力の影響は無視できるとし $\left(C_{3}=0\right), C_{2}$ を実験 結果に対し最小二乗法を用いてチューニングを行った. Levy は $C_{2}=0.015$ を提案しているのに対し，本実験結果 においては， $C_{2}=0.034$ を得た．Levy は主に高圧・高質量流束条件の実験結果（系圧力 $0.41 \sim 13.7 \mathrm{MPa}$, 質量流 束 $G=131.8 \sim 1437 \mathrm{~kg} / \mathrm{m}^{2} \mathrm{~s} ）$ を対象にしているのに対して，本実験では浮力の影響が顕著となる低圧・低質量流束 条件を対象としている，そのため，本実験条件では Levy に比べて蒸気泡径が大きくなることが考えられ， $C_{2} の$ 值が大きくなることは妥当な結果であると考えられる. 次に, 下降流の実験結果に対して, 浮力の影響を考慮し $C_{3}$ を含めてチューニングを行った．しかし，定性的にも十分な結果が得られなかった．また，下降流の実験結果 に対して, 浮力が流動方向に対向するということを表現するため, 式（8）の抗力項の符号を正から負に変更し再 
度チューニングを行ったが，実験結果との良い一致を示さなかった．以上のことから，Levy の相関式を用いて， 気泡に作用する力や，作用寸る力の向き違いから，上昇流と下降流の沸騰開始条件の違いを説明することは困難 であると考えられる，そこで，下降流についても上昇流と同様に浮力の影響を無視し $\left(C_{3}=0\right)$, チューニングを 行った結果, $C_{2}=0.025$ を得た.

以上のようにして得られた，上昇流（青実線）および下降流（赤実線）の沸騰開始条件の計算結果を，図 3 に 併記する．なお，熱支配と熱・流体支配の沸騰開始条件が重複する領域では，沸騰開始クオリティが低い条件が 先に満足されるものとした．また，図6に実験結果と本研究において提案する相関式を用いて計算した結果の比 較を示し，表 1 に各相関式の計算結果と実験結果の誤差の RMS を示す．なお，誤差の RMS は式（9）を用いて 算出した. 本研究で提案した相関式は, どの加熱長さ条件に対しても, 沸騰開始クオリティを 0.010 程度の誤差 の範囲内で収まっており，従来の相関式と比較しても，全実験条件については誤差が小さいことが分かる.

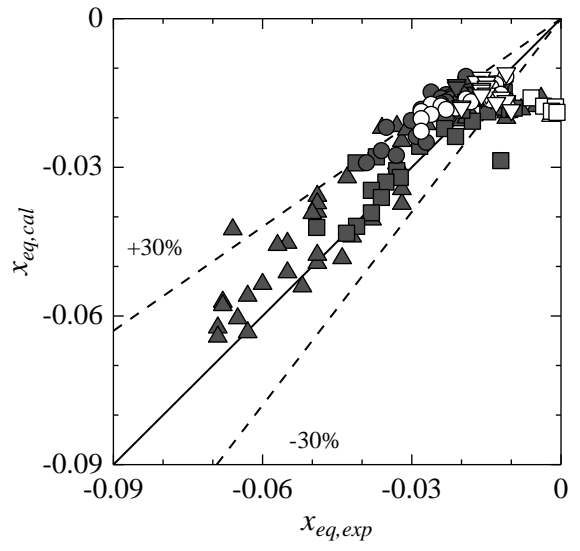

(a) Present model

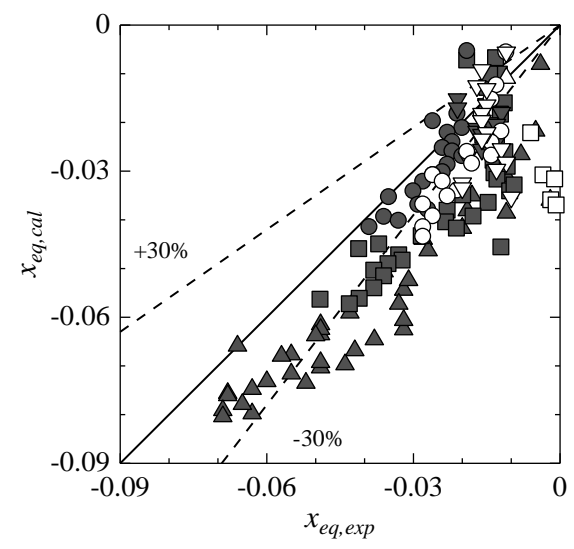

(b)Levy

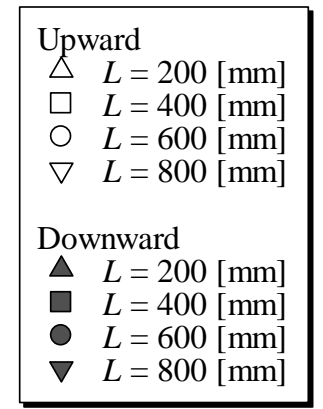

Fig.6 The comparison between experimental PNVG and calculated PNVG. The calculated thermal equilibrium quality under PNVG condition is plotted as a function of the experimental thermal equilibrium quality. Each shape of plots shows the heating length. The circle and solid plots correspond to the data of upward flow and that of downward flow, respectively. The calculation results based on the proposed model shows a good agreement with experimental results.

Table 1 Root mean square error of PNVG.

\begin{tabular}{c||c|c|c|c||c}
\hline \multicolumn{1}{c||}{ Correlation } & \multicolumn{4}{c||}{$L[\mathrm{~mm}]$} & \multirow{2}{*}{ All } \\
\cline { 2 - 5 } & 200 & 400 & 600 & 800 & \\
\hline Bowring & 0.0560 & 0.0418 & 0.0162 & 0.0154 & 0.0313 \\
Shah-Zuber & 0.0258 & 0.0270 & 0.0131 & 0.0136 & 0.0200 \\
Levy & 0.0213 & 0.0230 & 0.0079 & 0.0995 & 0.0152 \\
Present & 0.0122 & 0.0133 & 0.0063 & 0.0034 & 0.0087 \\
\hline
\end{tabular}

$$
x_{d, R M S}=\frac{1}{N} \sqrt{\sum_{i=1}^{N}\left(x_{d, \exp }-x_{d, c a l}\right)^{2}}
$$

以上の結果より，加熱長さが長い場合，熱流束が低いため，管内は熱力学的平衡に近い状態にあるものと考え られる，そのため，エンタルピのみで沸騰開始条件が決まり，沸騰開始クオリティは流動方向に関わらずほぼ一 定，もしくは緩やかに低下寸る特性を示すものと考えられる.この条件については，修正した Bowring の相関式 を用いて表現することが出来た，一方，加熱長さが短い場合，熱流束が非常に高いため，熱力学的非平衡が強い 流動場が形成されると考えられる。これにより下降流では，管内壁面近傍の過熱液層内を初期気泡が逆流して境 
界層を擋乱し，さらに上流側で凝縮し，エンタルピが上昇するため，熱平衡換算上の下降流の沸騰開始クオリテ イが上昇流よりも低くなったものと考えられる．修正した Levy の相関式を用いることで，実験結果と良い一致 を示寸結果を得たが, 単相乱流場に用いられる Kárman の一般速度分布に基づいて温度分布を与えているため, 蒸気の逆流による流動場への影響は考慮されていない，そのため，本質的な意味では上昇流と下降流の沸騰開始 点の差を説明できるわけではないが，擬似的に下降流の離脱気泡直径を上昇流のそれよりも小さくすることで， 本実験結果を表現したこととなる．この点については今後詳細な検討が必要になるものと考えられる.

\section{4. 結 言}

上昇流および下降流の伝熱実験を行い，テストセクション圧力損失から沸騰開始点を見積もり，その特性につ いて検討し, 以下の知見を得た。

加熱長さが長い，低加熱熱流束条件では，沸騰開始クオリティは質量流束に関わらずほぼ一定值を示したこと から，沸騰開始条件は熱支配によると考えられる．サブクール沸騰熱伝達率をチューニングした Bowring の相関 式を用いることで，実験結果を上手く表現することができた.

加熱長さが短い，高加熱熱流束条件では，沸騰開始クオリティは質量流束の増加とともに大幅に減少し，下降 流の沸騰開始クオリティの方が上昇流よりも低くなる傾向を示した．沸騰開始条件は熱・流体支配によると考え られる. Levy のモデルをチューニングすることで本実験結果と良い一致を示すことができたが，蒸気の逆流の影 響は十分に考慮できておらず，今後詳細な検討が必要になるものと考えられる.

\section{文献}

Bibeau, E.L. and Salcudean, M., The effect of flow direction on void growth at low velocities and low pressure, International Communications in Heat and Mass Transfer, Vol.17 (1990), pp.19-25.

Bowring, R. W., Physical model based on bubble detachment and calculation of steam voidage in the subcooled region of a heated channel, Report HPR10, OECD Halden Reactor Project (1962).

Lahey, Jr. R.T. and Moody, F.J., The thermal-hydraulics of a boiling water nuclear reactor, American Nuclear Society (1977), pp.211-226.

Levy, S., Forced convection subcooled boiling - Prediction of vapor volumetric fraction, International Journal of Heat and Mass Transfer, Vol.10, No.7 (1967), pp.951-965.

Saha, P. and Zuber, N., Point of net vapor generation and vapor void fraction in subcooled boiling, Proceedings of 5th International Heat Transfer Conference, Tokyo, Vol.4 (1974), pp.175-179.

日本機械学会編, 改訂＼cjkstart気液二相流技術ハンドブック (2006), pp.51-60.

\section{References}

Bibeau, E.L. and Salcudean, M., The effect of flow direction on void growth at low velocities and low pressure, International Communications in Heat and Mass Transfer, Vol.17 (1990), pp.19-25.

Bowring, R. W., Physical model based on bubble detachment and calculation of steam voidage in the subcooled region of a heated channel, Report HPR10, OECD Halden Reactor Project (1962).

Lahey, Jr. R.T. and Moody, F.J., The thermal-hydraulics of a boiling water nuclear reactor, American Nuclear Society (1977), pp.211-226.

Levy, S., Forced convection subcooled boiling - Prediction of vapor volumetric fraction, International Journal of Heat and Mass Transfer, Vol.10, No.7 (1967), pp.951-965.

Saha, P. and Zuber, N., Point of net vapor generation and vapor void fraction in subcooled boiling, Proceedings of 5th International Heat Transfer Conference, Tokyo, Vol.4 (1974), pp.175-179.

The Japan Society of Mechanical Engineers ed., Handbook of Gas-Liquid Two-Phase Flow Technology Second Edition (2006), pp.51-60 (in Japanese). 